\title{
Beta-thalassemia major
}

INSERM

\section{Source}

INSERM. (1999). Orphanet: an online rare disease and orphan drug data base. Betathalassemia major. ORPHA:231214

Beta-thalassemia (BT) major is a severe early-onset form of BT (see this term) characterized by severe anemia requiring regular red blood cell transfusions. 